\title{
DEVELOPMENT OF REFLEXIVE COMPETENCE WITH THE HELP OF THE PROJECT METHOD IN ENGLISH LANGUAGE TEACHING FOR STUDENTS OF THE SPECIALTY “INFORMATION SYSTEMS AND TECHNOLOGIES”
}

\author{
Nina Shvaikina \\ Samara State Technical University, Russian Federation
}

\begin{abstract}
The development of reflexive competence and the process of evaluating the results becomes a prerequisite for the formation of each student as a thinking, sociable and socially active person. Therefore, from the huge number of different pedagogical technologies used in universities, it is necessary to choose one that more contributes to the development of these qualities. We believe that this technology is project-learning technology by which the students learn to analyze and evaluate themselves, other participants in interaction and joint activities. We believe that the use of project learning technology in the form of the web-quest in the lesson contributes to the development of the ability to reflect. The problem of research is the optimization of ways to form reflexive competence through project training at English lessons. The purpose of the study: to form a reflexive competence using the method of projects in English lessons. Object of study: process of reflexive competence formation in students. The subject of the study: the use of project training technology in the formation of reflexive competence in students of specialty "Information systems and technologies". Experimental work was carried out in control and experimental groups among students of the above mentioned specialty. A total of 30 students participated in the experiment. The experimental and control group was an equal number of students - 15 people.
\end{abstract}

Keywords: reflexive competence, reflection process, IT students, English language teaching, project method, web-quest, internet resources for teachers.

\section{Introduction}

The priority goal of modern education is the development of a personality ready for self-education and self-development. According to the Federal State Educational Standard of Higher Education of 2016, special attention is paid to the formation of reflexive abilities. According to this document, graduates of a higher educational institution should have formed not only the ability of reflexiveevaluative activity, but also the ability to self-organization and self-regulation.

The standard focuses on the importance of implementation of students' assessment activities and, in turn, the formation of the reflexive competence. The 
research of this kind is currently being carried out by S.S. Kashlev, T.P. Leontyeva, V.D. Shadrikov, S. Hole and other researchers. The reflection allows the formation of personal and cognitive universal educational actions. Moreover, in connection with the changes taking place in modern society, it is important to maintain an interest in mastering any foreign language among students of linguistic and non-linguistic specialties. To do this, it is necessary to teach the student to analyze the content of his activities, evaluate it and plan a positive result. Obviously, reflection allows formation of self-control, selfesteem, self-regulation and the formation of a habit of comprehending events, problems, life, helps students to formulate the results obtained, redefine the goals of further work, and adjust their educational path.

As part of our research, we decided to focus on the use of project-learning technology. Many researchers study this problem: V.B. Lebedintsev, I.I. Mazur, E.S. Polat, V.N. Yanushevsky, A.V. Leontovich, N.A. Kralya, M. Holm, P. Blumenfeld and others.

In our opinion, project-based learning technology has a number of advantages over other methods. In addition, in the standard of higher education for bachelors in the field of "Information systems and technologies", special attention is paid to the method of projects within the framework of academic disciplines. The use of the technology of project activity is most effective, since it is characterized by an individual, communicative, practice-oriented orientation and is focused on the independent work of students, which contributes to the development of skills such as planning activities, projecting results, monitoring, analyzing and evaluating activities, correlating results and plans. It is these skills that determine the essence of reflection process.

However, in the existing practice of English language teaching (ELT) in higher educational institutions, the possibilities of project-based learning technology are not used sufficiently in the process of forming reflexive competence. The choice of the most optimal ways to form this personality quality of students through project-based learning determines the relevance and problem of our research.

The research problem is to optimize the ways of forming reflexive competence through project-based teaching in English lessons.

Purpose of the study: to form reflexive competence using the project method in English lessons for students of the "Information systems and technologies" specialty. students

Object of research: the process of formation of reflexive competence in

Subject of research: the use of project-based teaching technology in the formation of reflexive competence in students. 


\section{Literature Review}

In our opinion, the technology of project-based teaching should be applied in the implementation of programs of all academic disciplines, in particular, in English lessons. Thus, students will gain experience in project activities, as a special form of educational work, contributing to the education of independence, initiative, responsibility, increasing motivation and effectiveness of educational activities; in the course of implementing the initial concept at a practical level, they will master the ability to choose adequate means of the task at hand, to make decisions, including in situations of uncertainty. They will have the opportunity to develop the ability to choose several options for solutions, to search for nonstandard solutions, to find and implement the most acceptable solution. Before introducing project-based learning into the educational process, we need to present a literature review in this topic.

Russian and foreign academicians (A.V. Leontovich, E.S. Polat, M.Y. Oleshkov, P. Blumenfeld, etc.) specialize in the study of the technology of project-learning technology. Today there are many different definitions of the concept of "project learning technology". Let's consider some of them.

E.G. Azimov defines it as one of the teaching technologies, including a foreign language, based on modeling social interaction in a small group during the educational process (Azimov, 1999)

According to V.V. Davydov, the technology of project-based learning is a learning system in which students acquire knowledge and skills in the process of planning and performing gradually more complicated practical tasks - projects (Davydov, 1999).

M.Y. Oleshkov, on the other hand, understands it as a teaching method that guides students towards creating a joint educational product (Oleshkov, 2006)

European methodologists give various definitions of the technology of project technology. P. Blumenfeld considers it as an integrated approach to teaching, focused on involving students in research. In these conditions, they seek solutions to non-standard problems by asking questions, discussing ideas, making predictions, developing plans, collecting and analyzing data, drawing conclusions, passing them on to others and creating the final products of educational activities (Blumenfield, 1991).

According to T. Markham's definition, project-based learning technology is a method that stimulates students to study a school subject, acquire new knowledge and skills by solving complex, authentic and carefully designed problems by a teacher (Markham, 2003).

M. Holm understands it as a teaching method that makes students find solutions to specific problems. He notes that project-based learning is student- 
centered. They select, plan, research, and manufacture a product by answering a question that is directly related to true to life issues (Holm, 2011).

We see that, despite the differences in definitions, the opinions of the authors agree that the technology of project-based teaching is focused on the independent work of students in obtaining knowledge, skills and experience, while the final product has practical value for students. In addition, all researchers are convinced that it is a practice of joint activity between the participants of the educational process and is based on the following principles:

- $\quad$ the principle of individualization: an individual approach is carried out and thus favorable conditions work for the development of individual abilities.

- the principle of communicative orientation: in the project activity, it is assumed that there are certain relationships between the participants in the educational process.

- the principle of self-study: students have the opportunity to show initiative and independence in the educational process. They independently determine the goals and objectives of the activity; select the necessary material using a variety of information sources; plan the content of the activity and carry it out, achieving the desired result.

Thus, we see that a project is a plan and product of students' independent research work or project activity. Consequently, project-based learning is a technology for the implementation and organization of project activities of students.

Currently, there are several classifications of projects. English specialists in the field of language teaching methodology distinguish between three types of projects: group, in which research is carried out by the whole group, and each student studies a specific aspect of the chosen topic; mini-research, consisting in conducting a sociological survey using questionnaires and interviews; a project based on work with literature, implying selective reading on a topic of interest to the student. At the same time, mini-research and work with literature can be considered as a kind of group project. In our opinion, this is an insufficiently complete classification. In this connection, we will rely on the classification of projects proposed by Russian teachers (E.S. Polat, N.A. Kralya, V.N. Yanushevsky, etc.). Depending on the leading type of activity carried out by students, the above mentioned researchers distinguish:

- $\quad$ research projects that require a well-built structure, designated goals, the relevance of the research subject for all participants, and social significance.

According to V.N. Yanushevsky, this type of projects involves argumentation of the relevance of the topic taken for research, formulation of the research problem, its subject and object, designation of research tasks in the 
sequence of the adopted logic, hypotheses for solving the indicated problem, development of ways to solve it, discussion of the results obtained, conclusions, registration of research results, identification of new problems for the further development of the study (Yanushevsky, 2011).

E.S. Polat clarifies that any project requires a creative approach, and in this sense, they can all be called creative. But when determining the type of project, researchers identify the dominant type of activity. Creative projects presuppose the appropriate design of the results. They, as a rule, do not have a detailed structure of joint activities of the participants. At first it is only outlined and further develops, subject to the genre of the final result (Polat, 2000)

However, according to V.N. Yanushevsky, the presentation of the results of the project requires a well-thought-out structure in the form of a script for a film or play, a holiday program, an essay plan, an article, design and headings of a newspaper, etc. Such projects should be implemented in group work.

- information projects are aimed at collecting information about an object, phenomenon. It is supposed to familiarize the project participants with this information, analyze it and summarize the facts intended for a wide audience.

According to N.A. Kralya, such projects, like research projects, require a well-thought-out structure, the possibility of systematic correction along the way. The structure of such a project can be designated as follows: the purpose of the project, its relevance.

So, summarizing and denoting the relationship between reflexive competence and the technology of project-based learning, we once again note:

1. Students themselves learn, discover, comprehend and apply the knowledge gained. Project activity puts students in front of the need to find and make the best decision. This allows a teacher to individualize the learning process and make it more intensive, giving students the opportunity to choose the pace of progress towards the final learning outcomes.

2. It enables students to collaborate with each other, listen to each other and develop interpersonal skills. Working on a project allows you to gain experience before being involved in professional activities.

3. The learning process is as close as possible to practice. Participation in such activities increases the level of English language proficiency, forms the skills of independent activity, initiative, since project-based training offers to independently analyze information from various English-language sources and draw appropriate independent conclusions.

Thus, we believe that project-based learning technology can improve the educational process. This is possible because it is focused on the individuality and 
independence of students, on the practical application of knowledge and creativity. This nature of the activity is necessary for students, as it motivates them to learn. At the same time, the conditions for the successful development of reflexive competence coincide with the conditions for the effective use of technology. These include student autonomy, planning, analysis and performance evaluation. Therefore, in our opinion, the use of this teaching technology in the classroom of the English language will contribute to the effective formation of reflexive competence.

\section{Sample Selection}

The leading component of the professional competence in general of a future IT bachelor is knowledge, skills, abilities and personal qualities that allow to design information systems that have the potential to solve problems that will arise in the future, and currently have a high level of uncertainty. It becomes evident that to carry out these professional duties, an IT student needs to possess reflexive competence.

Experimental work was carried out in control and experimental groups among students of the faculty "Information systems and technologies". A total of 30 students participated in the experiment. The experimental and control group was an equal number of students - 15 people.

\section{Methodology}

As a result of mastering the bachelor's program, the graduate must have the competences established by the bachelor's program. The set of competencies established by the bachelor's program must provide a graduate of a higher educational institution with the ability to carry out professional activities in at least one area of professional activity and (or) area of professional activity, established in accordance with paragraph 1.11 of the Federal State Educational Standard of Higher Education, and to solve the problems of professional activity at least, than one type.

Based on the Federal State Educational Standard of Higher Education undergraduate in Information systems and technologies, we can determine the components of reflection of oneself and one's own activity, reflection of joint activity, reflection of the participants in the interaction.

1. Reflection of oneself and one's own activity:

- the ability to independently determine the goals of education, to set and formulate tasks for themselves in activities;

- $\quad$ ability to work individually; 
- possession of the basics of self-control, self-assessment in activities.

2. Reflection on joint activities:

- the ability to plan ways to achieve goals, including alternative ones, together with others;

- ability to organize interaction with clients and partners in the process of solving management problems

- $\quad$ the ability to monitor activities in the process of achieving a result; adjust your actions in accordance with the changing situation; correlate actions with planned results.

3. Reflection of the participants in the interaction:

- the ability to find a common solution and resolve conflicts based on coordination of positions and consideration of interests;

- $\quad$ the ability to analyze and evaluate the behavior and activities of participants in the process.

Tests for determining the level of reflexive competence formation were developed by T.F. Usheva. These tests are aimed at assessing the formation of various components of reflection. We believe that the test developed by T.F. Usheva is the appropriate one for determining the level of reflexive competence. The researcher proposes to use it in the classroom of any academic subject, including English. The assignments make it possible to assess the level of formation of each of the reflection components, as well as the achievement of the planned results of the project-based learning technology.

At the same time, before the start of project activities, the teacher needs to fix the level of formation of reflection in order to determine how well students have developed the skills of analyzing and evaluating themselves, joint activities and its participants in order to track the development of skills in dynamics.

We recommended to focusing on the following indicators for assessing results:

Table 1 Indicators for Assessing Educational Results

\begin{tabular}{|c|l|c|}
\hline Score indicator & \multicolumn{1}{|c|}{ Description } & Points \\
\hline 1 & \multicolumn{1}{|c|}{2} & 3 \\
\hline $\begin{array}{c}\text { high level of } \\
\text { formation of } \\
\text { reflection }\end{array}$ & $\begin{array}{l}\text { The student is able to analyze his own interests, plan } \\
\text { activities and predict its possible results. It does not seem } \\
\text { difficult for him to organize his own and joint activities } \\
\text { to achieve the goal, as well as correlate the result with the } \\
\text { goal. He is able to coordinate and control activities in } \\
\text { accordance with changing conditions, exercising self- } \\
\text { control, self-assessment and evaluating the activities and } \\
\text { participants in the interaction. }\end{array}$ & 5 \\
\hline
\end{tabular}


Shvaikina, 2021. Development of Reflexive Competence with the Help of the Project Method in English Language Teaching for Students of the Specialty "Information Systems and Technologies"

\begin{tabular}{|c|l|c|}
\hline $\begin{array}{c}\text { average level of } \\
\text { reflection } \\
\text { formation }\end{array}$ & $\begin{array}{l}\text { The student has little difficulty in carrying out } \\
\text { independent activities. It is difficult for him to organize } \\
\text { his own or joint activity in changing conditions, to plan } \\
\text { it, to design its results. He can carry out introspection and } \\
\text { self-assessment and evaluate work partners. }\end{array}$ & 4 \\
\hline $\begin{array}{c}\text { the level of } \\
\text { formation of } \\
\text { reflection is below } \\
\text { average }\end{array}$ & $\begin{array}{l}\text { The student does not know how to analyze and evaluate } \\
\text { himself and the behavior of other people. He experiences } \\
\text { significant difficulties in planning, designing results and } \\
\text { organizing independent activities. It is difficult for him to } \\
\text { work in a constantly changing environment. }\end{array}$ & 3 \\
\hline $\begin{array}{c}\text { low level of } \\
\text { formation of } \\
\text { reflection }\end{array}$ & $\begin{array}{l}\text { The student does not know how to plan and organize } \\
\text { independent activities. He does not have the skills to } \\
\text { analyze and evaluate himself, his own and joint activities } \\
\text { and behavior of other people. }\end{array}$ & 2 \\
\hline
\end{tabular}

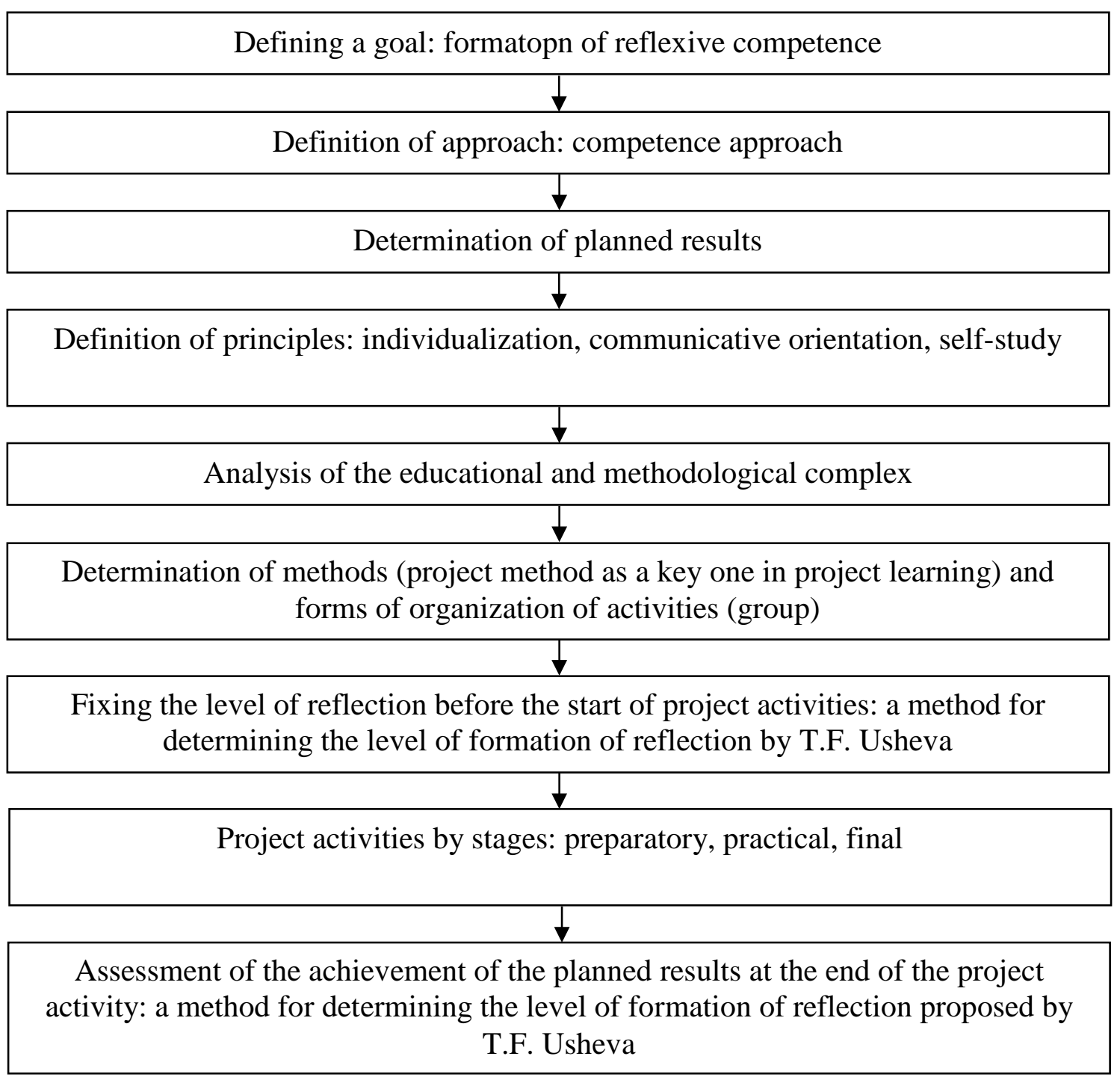

Figure 1 Model of project learning technology 
We believe that the process of reflexive competence formation will be successful if the technology of project learning is used. The technology considered in the framework of our research, as noted earlier, allows individualizing the educational process, develops interpersonal interaction skills, and forms the skills of independent activity.

Let's give an example of the project-based learning technology model we are designing.

So, the creation of a project should take place in the process of studying one module. Therefore, the plan for organizing the project activities of students can be presented in the form of the following model.

The plan is given taking into account the duration of one lesson at the university.

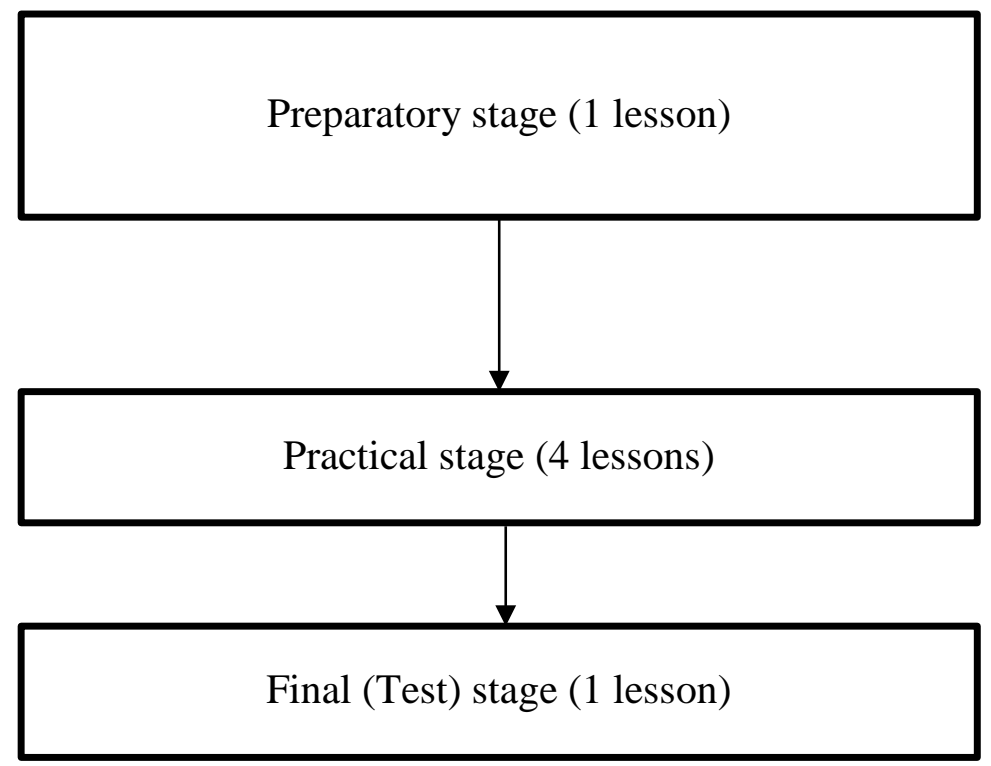

Figure 2 Plan of the organization of project activities of student

\section{The Description of the Experiment}

\section{Preparatory stage}

As today we are working in the format of distance learning as a result of tremendous consequences of COVID-19, we have also thought about how to organize the work of students with the teacher under these circumstances. In our modern world because of pandemia the technologization of modern linguistic education is developing at a rapid space (Aleksandrova, 2020) In this case we can suggest web-quest as a form of project-based technology.

Web quest is one of the newest teaching tools, and is focused on improving the effectiveness of the foreign language learning process. The essence of the 
technology is that the students should collect the necessary materials on the selected problem in the Internet sources (Shvaikina, 2020) References to some sources are provided by the teacher, students must find some of the links themselves. Upon completion of the work on the topic, the learners should present the results in the form of their own web pages, electronically, in print or orally. The advantage of implementing a Web quest is that no specific technical knowledge is required for the event. You can work on a quest individually, or in small groups. The website used to develop the web quest was http://zunal.com.

Web-quests have a great potential for development trans-national joint projects (Gradaleva \& Houston, 2018) that can enhance development of transprofessional skills of the future specialists (Oparina \& Gridneva, 2019).

At the preparatory stage type of project, its name and time frame are determined (information project, "What makes a person successful? Describe a successful person")

The key task of the project: "Imagine that you are the editors of a city newspaper. You should write an article on a given topic.

Project creation context: "You need to divide into groups, write an article on a given topic. Publish your information in the students' newspaper."

At this stage, the teacher needs to introduce the topic of the project and familiarize students with the project assignment. Then the students are divided into groups of 5-6 people and choose a person whose biography they would like to highlight, and determine the purpose of the project activity - to present an article or a project about a successful person and what factors make a person successful in business.

Then students need to identify their own interests and what needs to be done to create a project (Table 2).

Table 2 Questions to be determined by students own interests and needs

\begin{tabular}{|l|l|}
\hline $\begin{array}{l}\text { Before starting your project work answer the } \\
\text { following questions: }\end{array}$ & $\begin{array}{l}\text { Planned results: } \\
- \\
\text { the ability to independently determine the } \\
\text { goals of their learning, to set and } \\
\text { formulate tasks for themselves in learning } \\
\text { 1. Why did I choose this topic? }\end{array}$ \\
$\begin{array}{ll}\text { 2. What do I know about this topic now? } \\
\text { 3. What do I want to know? }\end{array}$ & $\begin{array}{l}\text { ability to work individually; } \\
\text { 4. What do I need to make the project? } \\
\text { 5. What should I do to make it? }\end{array}$ \\
\end{tabular}

Based on the answers, you should define a work plan, the implementation of which will lead to the achievement of the goal. It must be reflected in the diary of project activities. Students should conduct it to analyze and evaluate group work. 


\section{Practical stage}

At this stage, the teams implement the planned actions, reflecting the difficulties encountered and the results of the work in the project diary.

Table 3 Project Diary

\begin{tabular}{|c|c|c|}
\hline \multicolumn{3}{|c|}{ Project diary } \\
\hline 1 & 2 & 3 \\
\hline Actions of each member of the group & Difficulties & Result \\
\hline \multicolumn{3}{|c|}{ Searching for necessary information } \\
\hline $\begin{array}{l}\text { Example of a students' answer: } \\
\text { Everyone is analyzing information. } \\
\text { We are selecting information that } \\
\text { we may use in our work. }\end{array}$ & $\begin{array}{l}\text { Example of a students' } \\
\quad \text { answer: } \\
\text { It was difficult to find } \\
\text { necessary information. }\end{array}$ & $\begin{array}{l}\text { Example of a students' } \\
\text { answer: } \\
\text { We have much } \\
\text { information about the } \\
\text { theme that we have } \\
\text { chosen. We are ready for } \\
\text { the next step. }\end{array}$ \\
\hline \multicolumn{3}{|c|}{ Answering the questions } \\
\hline $\begin{array}{l}\text { Example of a students' answer: } \\
\text { We have divided questions. } \\
\text { Student } 1 \text { is answering questions } \\
\text { about success criteria. } \\
\text { Student } 2 \text { is writing about a } \\
\text { successful person. } \\
\text { Student } 3 \text { is writing about success } \\
\text { in business. } \\
\text { Student } 4 \text { is answering questions } \\
\text { about the difference between } \\
\text { successful and unsuccessful people. } \\
\text { Student } 5 \text { is writing about some } \\
\text { interesting facts of business. }\end{array}$ & $\begin{array}{l}\text { Example of a students' } \\
\text { answer: } \\
\text { Some students were } \\
\text { doing it too long. It } \\
\text { retarded our project } \\
\text { work. }\end{array}$ & $\begin{array}{l}\text { Example of a students' } \\
\text { answer: } \\
\text { We have all questions } \\
\text { answered. We are ready to } \\
\text { write an article. }\end{array}$ \\
\hline \multicolumn{3}{|c|}{ Writing an article } \\
\hline $\begin{array}{l}\text { Example of a students' answer: } \\
\text { Student } 1 \text {, Student } 2 \text { and Student } 3 \\
\text { are making the article using } \\
\text { information that was found in the } \\
\text { last step. } \\
\text { Student } 4 \text { and Student } 5 \text { are } \\
\text { correcting the article. }\end{array}$ & $\begin{array}{l}\text { Example of a students' } \\
\quad \text { answer: } \\
\text { It was difficult to } \\
\text { gather the whole group. }\end{array}$ & $\begin{array}{l}\text { Example of a students' } \\
\quad \text { answer: } \\
\text { We have done the whole } \\
\text { article. }\end{array}$ \\
\hline
\end{tabular}


The teacher should be aware of the success of the students' activities. To do this, he should regularly hold consultations, where students should report on the work done. The teacher should identify the difficulties arising in the process of project activities. They can be associated both with the search and analysis of information, and with the organization of joint activities in a group. In this case, the teacher should give students the opportunity to analyze the activity. To do this, during the consultation, they fill out a Difficulty Assessment Sheet.

\section{Table 4 Difficulty Assessment Sheet}

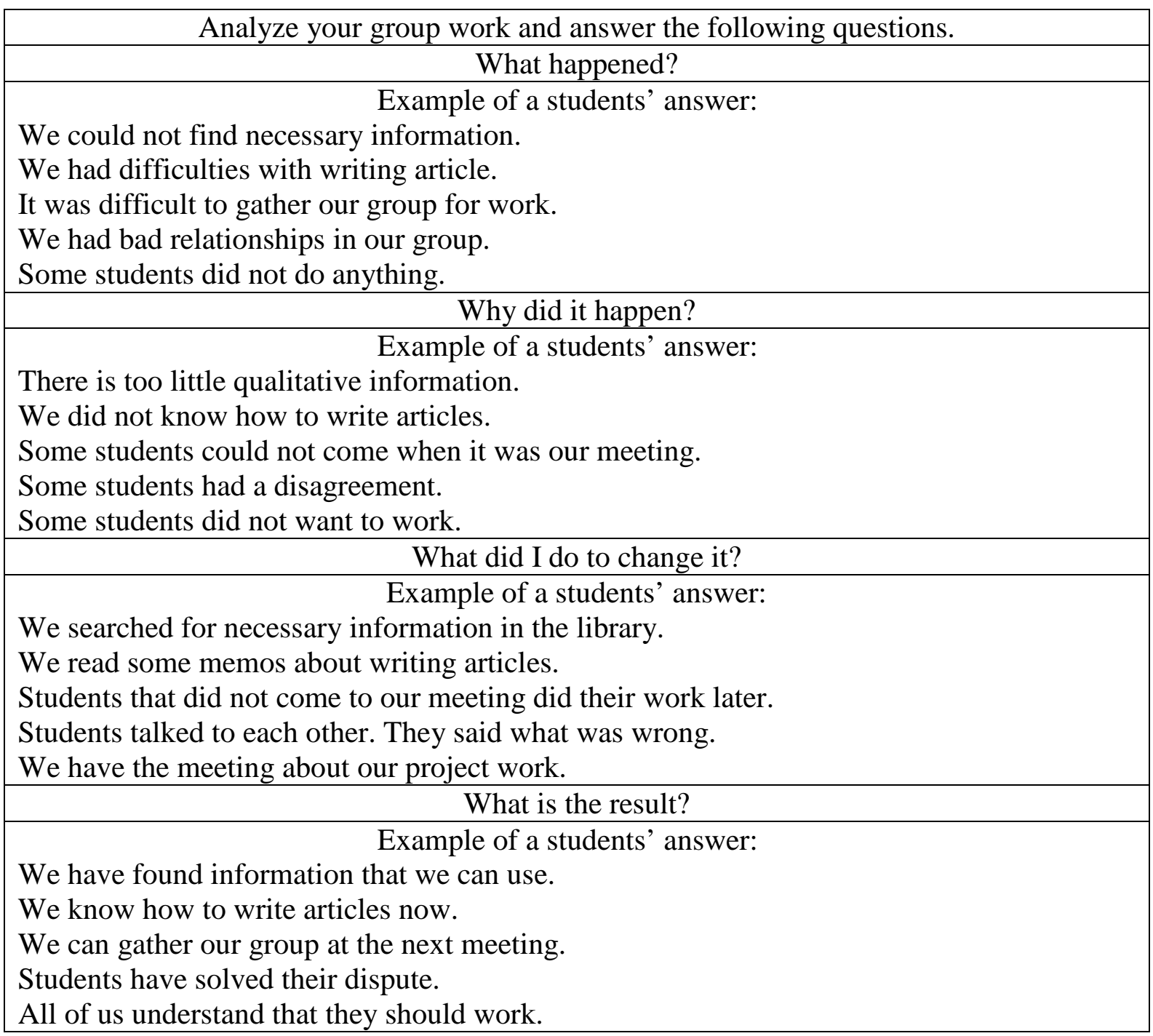

Final (test) stage

Students finish their project activities by designing a students' newspaper and presenting their topic to other groups. After the presentation of the project, it is necessary to organize a round table discussion. For this, students are invited to analyze the contribution of each to the group project and the nature of the 
interaction. Based on this data, the teacher can evaluate the project activity. They should first fill out a score sheet (Table 5).

\section{Table 5 Assessment Sheet}

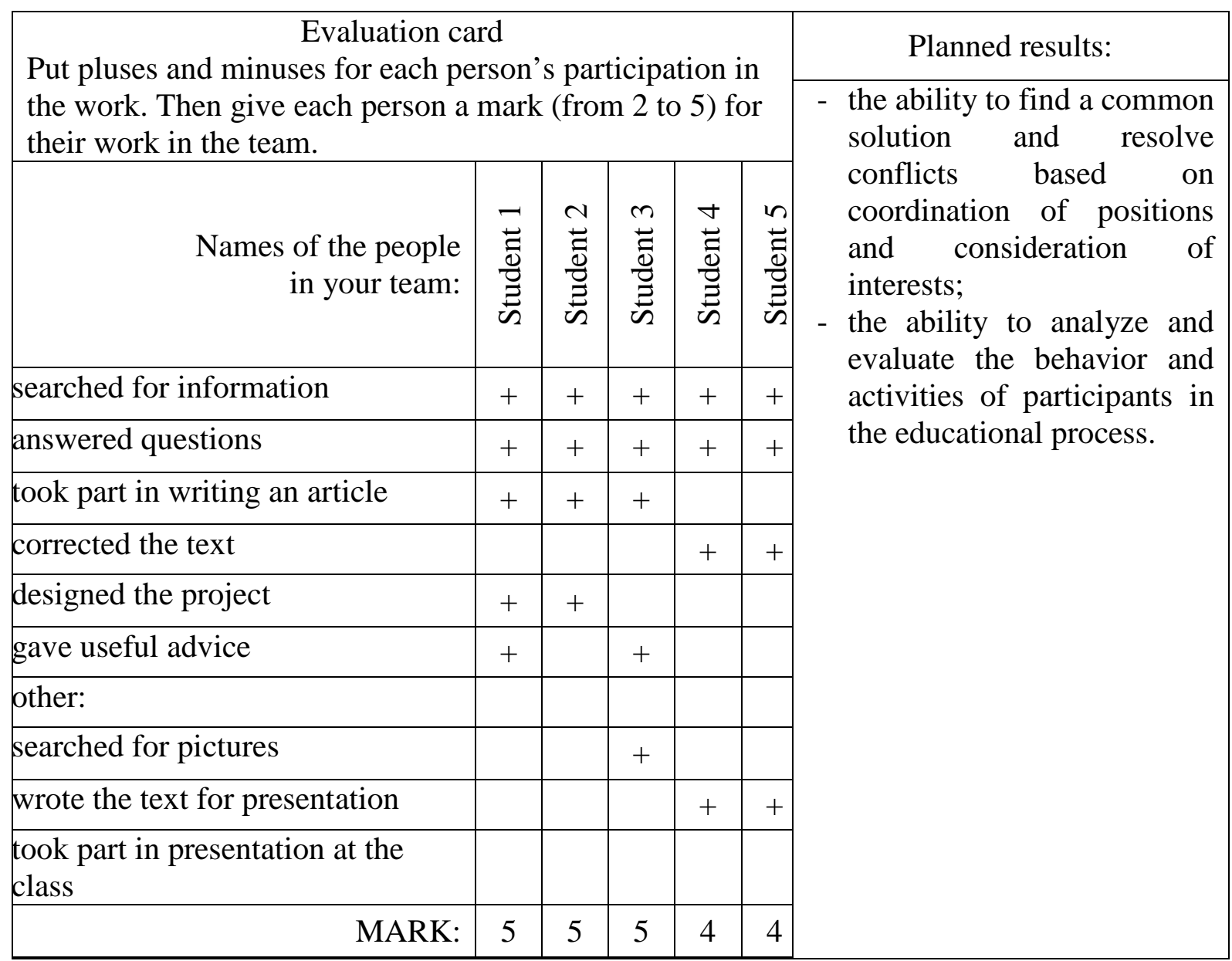

At the end of the project activity, the teacher must again fix the level of formation of reflection in order to track the dynamics of its development in children and evaluate the achievement of the planned results. We recommend using the questionnaire by T.F. Usheva.

\section{Recommendations for the Organization of the Project Work}

1. The project should begin with the choice of the project topic, definition of its problem and purpose. They are put forward by students at the suggestion of the teacher through leading questions, situations that contribute to the definition of problems, etc. 
2. An important point is the distribution of tasks into groups. The teacher should organize a discussion of possible creative solutions and information retrieval. This is necessary for involvement of students in the work.

3. It is necessary to have regular mid-term discussions of the work done so that the students are aware of what they have already done and what they have to do. This is essential for building reflexive competence.

4. Project activities should be completed with collective discussion and formulation of conclusions.

5. The activity should be personally significant, important for the student. Therefore, the teacher should help students understand the meaning of their project activities, see the possibility of realizing their capabilities.

6. It is necessary to create such an atmosphere for project activities to maintain interest in these activities, a situation of success.

7. The teacher must create psychological comfort. The educator must support and guide them; must become their mentor, partner.

\section{Conclusion}

Summing up the results of the study, it should be noted that the problem of the formation of reflexive competence and determination of its place in the educational process using the technology of project-based teaching in English lessons is relevant. This is due to the fact that today the process of forming this type of skill through work on projects has not been organized. The use of projectbased teaching technology in English lessons can be an effective way to form reflexive competence, as it characterized by an individual, communicative, practice-oriented focus and based on the independent work of students, which contributes to the development of skills such as planning activities, projecting results, monitoring, analysis and performance evaluation, correlation of result and plan. These skills that are required in the professional activities of students in the Information systems and technologies specialty.

To carry out diagnostics before using the technology of project training and to monitor the achievement of educational results at the end of project activities, we proposed a system for assessing the achievement of planned results. To do this, we recommend using the method for determining the level of reflection, which was developed by T.F. Usheva.

The description of the project-based learning technology we are investigating, practical recommendations for its implementation and the development of a complex of projects within the framework of thematic planning of teaching materials give us grounds to assume that the use of project-based learning technology in the formation of reflexive competence is effective at every stage. 


\section{References}

Alexandrova, E.V. (2020). Technologization of modern foreign language education. The Scientific Heritage, 5 (50), 34-36.

Azimov, E.G. (2009). New dictionary of methodological terms and concepts (theory and practice of teaching languages), 448-449. M: IKAR

Blumenfeld, P.C. (1991). Motivating project-based learning: sustaining the activity, supporting the learning, Educational Psychologist, 380-381.

Davydov, V.V. (1999). Russian Pedagogical Encyclopedia: in 2 volumes (1200-1201). M: Great Russian Encyclopedia

Gradaleva, E., Houston, M. (2018). Transnational projects in higher education development of intercultural communication skills by means of joint research. Proceedings of the International Scientific Conference, Volume I, 124-138.

Gridneva, N.A., Oparina, K.S. (2019). Formation of transprofessional competences in a number of new tasks of the methods of teaching foreign languages. Bulletin of the Samara State Technical University. Series: Psychological and pedagogical sciences, 3 (43), 42-54.

Hole, S. (1999). Reflection is at the heart of practice. Supporting New Teachers, 8, 34-37.

Holm, M. (2011). Project-based instruction: A Review of the Literature on Effectiveness in Prekindergarten through 12th Grade Classrooms. Rivier academic journal, 2, 2-32.

Kashlev, S.S. (2002). Modern technologies of the pedagogical process: A guide for teachers, 95-96. M: Higher school.

Kralya, N.A. (2005). The method of educational projects as a means of enhancing the educational activities of students, 59-60. Omsk: OmSU.

Lebedintsev, V. B. (2007). Collective training sessions - a special type of educational process. Collective teaching method: Scientific and methodological journal, 9, 14-35.

Leontovich, A.V. (2006). Organizational and substantive problems of the development of research activities of students. Research activities of students in the modern educational space: collection of articles,112-116. M: Research Institute of School Technologies.

Leontyeva, T.P. (2015). Methodology of teaching a foreign language: textbook. (234). M.: Higher school.

Markham, T. (2003). Project-Based Learning Handbook: A Guide to Standards-Focused Project-Based Learning for Middle and High School Teachers, 11-12. Novato

Mazur, I.I. (2005). Project management, pp.655. M: Omega-L.

Ministry of Education and Science of Russia. (2015). "On the approval of the federal state educational standard of higher education in the field of training 03.09.02 Information systems and technologies (bachelor's level)" [Electronic resource]: order of the Ministry of Education and Science of Russia dated 03.12.2015 No. 219 (Registered in the Ministry of Justice of Russia 03.30.2015 No. 36623). - Access mode: URL: http://gosvo.ru/uploadfiles/fgosvob/090302.pdf

Oleshkov, M.Yu. (2006). Modern educational process: basic concepts and terms, 19-20. M: Company Sputnik.

Polat, E.S.(2000.) Method of projects in foreign language lessons. Foreign languages at school, 2, 31-36.

Shadrikov, V.D. (2012). The role of reflection and reflexivity in the development of students' abilities. Journal of the Higher School of Economics, 4, 133-144.

Shvaikina, N.S. (2020). Use of web-quest technology in teaching foreign languages in a technical university. Perspectives and priorities of teacher education in the era of 
Shvaikina, 2021. Development of Reflexive Competence with the Help of the Project Method in English Language Teaching for Students of the Specialty "Information Systems and Technologies"

transformations, choices and challenges. Collection of scientific papers of the VI Virtual International Forum on Teacher Education, 240-244.

Usheva, T.F. (2007). Formation and Monitoring of Reflexive Skills of Students: Methodological Guide, pp.88. Krasnoyarsk.

Yanushevsky, V.N. (2017). Educational and social design in basic and high school: a methodological guide, pp.224. M: September. 